\title{
Assessment and Monitoring Protocols to Guarantee the Maintenance of Biodiversity in Certified Forests: A Case Study for FSC (Forest Stewardship Council) Forests in Southwestern Spain
}

\author{
Antonio J. Sánchez-Almendro ${ }^{1}$, Pablo J. Hidalgo ${ }^{1, *}$, Rosario Galán ${ }^{2}$, José M. Carrasco ${ }^{3}$ and \\ Javier López-Tirado ${ }^{1}$ \\ 1 Departamento de Ciencias Integradas, Universidad de Huelva, 21071-Huelva, Spain; \\ lauranto07@gmail.com (A.J.S.-A.); javier.lopez@dbasp.uhu.es (J.L.-T.) \\ 2 FSC International Center GmbH, Adenauerallee 134, 53113 Bonn, Germany; r.galan@fsc.org \\ 3 Ence, Energía y Celulosa, Crtra. A-5000, km 7.5, 21007-Huelva, Spain; jcarrasco@ence.es \\ * Correspondence: pablo.hidalgo@dbasp.uhu.es; Tel.: +34-959-21-9886
}

Received: 4 August 2018; Accepted: 10 November 2018; Published: 14 November 2018

\begin{abstract}
Biodiversity, sustainable development and nature conservation are fundamental issues nowadays. All companies, administrations, governments and international organisations take these issues into consideration. Sustainable forest management always requires a compromise between profitability and conservation and in this fragile equilibrium, forest certification plays a key scheme. This sustainable management is of great importance in the European Union (EU), with the Forest Stewardship Council playing a fundamental role in forest certification. This certification forms the basis of the ecosystem conservation and improvement strategy in Ence, Energía y Celulosa, the leading company dedicated to the production of eucalyptus in Spain; (2) A three-phase protocol (identification of High Conservation Values, assessment of conservation areas and monitoring program), has been developed, providing clear, objective criteria, particularly concerning FSC (Forest Stewardship Council) Principle 9, the primary goal being the development and application of these objective criteria in the Ence conservation areas in the province of Huelva (Spain). One of the main criteria for habitat classification was correspondence with the habitats listed in Annex I of the Habitats Directive. The compatibility between forest exploitation management and conservation proposed by the Natura 2000 network encouraged us to use this methodology for the identification, classification and assessment of High Conservation Values considered in FSC forest certification: Principle 9; (3) The study encompasses 183 forest management units covering 52,022 ha, with a total of 11,847.45 ha being identified as High Conservation Value Areas. Through the identification and assessment of the conservation areas, the described methodology played a crucial role in demonstrating the positive impact of Ence's certified forest management on the conservation of biological diversity; (4) This study demonstrates that an objective and reliable identification, assessment and monitoring methodology, with a proven high degree of accuracy in the location and characterisation of interesting and representative habitats in the region, can be implemented. Due to its objectivity, this strategy can be easily applied to other European sustainable forest management sites and possibly to other countries outside the EU.
\end{abstract}

Keywords: Forest Stewardship Council; FSC; sustainable forest management; High Conservation Values; forest certification; Habitats Directive; southern Spain; biodiversity 


\section{Introduction}

Commitment to sustainable forest management originated in the 1992 Rio de Janeiro Earth Summit on Environment and Development. Then, in 1993, the second Ministerial Conference on the Protection of Forests in Europe (MCPFE), held in Helsinki, defined sustainable forest management as the administration and use of forests and forest lands in a manner and intensity that allows the maintenance of their biodiversity, productivity, capacity for regeneration, vitality and potential to perform important ecological functions and so forth. MCPFE resulted in valuable achievements regarding the protection and sustainable management of European forests to tackle the challenges of the future [1]. More recently, this sustainable management has been adopted by many European Union (EU) member states where forest certification has become a fundamental mainstay [2]. Many forest criteria and indicators have been developed with the aim of improving forest biodiversity conservation policy targets [3]. Some attempts have been made to cement the definition of forest habitat types [4] in the Habitats Directive [5] framework. Nevertheless, an approach is needed to select indicators that provide stakeholders with confidence that their values are being upheld [6].

During the Rio Earth Summit, a forum was held where the establishment of a non-governmental, independent and international forest certification system that would promote environmentally responsible and sustainable forest management was proposed. This paved the way for the creation of the Forest Stewardship Council (FSC), established in 1993 as an international non-profit organization that pursues environmentally appropriate, socially beneficial and economically viable forest management. FSC facilitates the sustainable production of wood and non-timber forest products whilst maintaining the biodiversity, productivity and ecological processes of the forest, without losing respect for the rights of the workers and the communities that live and depend on these forests [7].

Sustainable forest management always requires a compromise between profitability and conservation. In this fragile equilibrium, forest certification plays a fundamental role, [8] serving as a tool by which consumers can make informed choices, opting for products from well-managed forests. Although there are many forest certification schemes, the FSC certification commands the highest respect worldwide. Furthermore, there is a strong consensus that FSC certified forests achieve higher levels of sustainable forest management compared to those using other certification schemes [9]. Though FSC certifies all types of forests and rights of ownership around the world, in some countries, such as Spain, it is often recommended for public ownership, most likely due to levels of cost and demand [2]. Nevertheless, in the case of small, privately-owned forests, FSC has several initiatives in place to support their certification, such as the creation of group certificates. In the case of ENCE, the company was formerly publicly owned but has since become the first private forestry company in Spain. Despite this change in ownership, they remain firmly committed both to the conservation of the biodiversity of their heritage and to their customers and this is reflected in the manner in which they implement their certification process.

In addition to the production of eucalyptus pulp, Ence, Energía \& Celulosa, the main company dedicated to eucalyptus production in Spain, also generates renewable energy using forest biomass [10]. Established in 1957 by the National Institute of Industry as a National paper mill Company, in 2004 it became the first paper mill factory in the world to be certified by the two main systems: PEFC (Program for the Recognition of Forest Certification Systems) and FSC [11]. Though Ence owns most of the forests that it manages, in some cases it has contracts for the rental and management of forests owned by others. This rent is legally recognised and registered and does not constitute any problem or conflict. All boundaries are clearly mapped and identified and the rental and management conditions are hitherto freely agreed upon and registered in writing accordingly. Ence's national ecosystem conservation and improvement strategy [12] is fundamentally based on the FSC principles, Principle 9 [7] in particular and is specifically focused on conservation areas-those portions of the certified forest management unit for which conservation is the sole objective-which include representative sample areas, conservation zones, protected areas, connectivity areas and High Conservation Value Areas (HCVAs). Although the concept of HCV was developed originally by FSC for forests certification, 
in 2005 was established the High Conservation Values Resource Network (HCVRN) [13] with the purpose to promote the HCV approach as a resource management tool, extending the concept of $\mathrm{HCV}$ forest to HCV area. To support forest managers complying with the conservation of HCVs and auditors evaluating their activities, there are currently several guidance documents that help identify, assess and monitor HCVs. A good practices guide was recently published with the aim to widen scope of use of HCV [14,15]. FSC is also working on a template to develop National HCV Frameworks [16]. There are currently 21 National HCV Frameworks, 4 of them in Europe.

Standardisation should involve the use of unique and well-defined criteria for the evaluation of habitats, such as present and potential area, minimum area and degree of isolation, number of characteristic species, presence of exotic or endangered flora and presence of recent forest fires. These parameters are relatively easy to evaluate following a pre-established standard scale. These monitoring criteria should prioritise areas of particular interest, sensitivity, notable fragmentation and so forth, that require the establishment of a more frequent monitoring strategy.

Our primary goal has been the development and application of these objective criteria in the Ence conservation areas in the Spanish province of Huelva. This could allow us to establish an identification and evaluation protocol and to develop a periodic monitoring strategy to be implemented over an indefinite period of time. This methodology could provide not only ready-to-use criteria, which allow the forest manager to identify, assess and monitor the HCVAs but also an objective and replicable methodology, in association with the Habitats Directive, which facilitates the comparison of data among regions and countries. The final goal is to test the effectiveness of this protocol and to prove that it can be applied to other exploited forest sites anywhere in Europe.

\section{Materials and Methods}

\subsection{Area of Study}

Figure 1 shows the distribution of Ence's forest management units (FMUs) in the province of Huelva. Most of the forests are found inland in areas of greater or lesser relief within the Sierra Morena mountain range. Nevertheless, the presence of some patches in coastal areas and in the surroundings of the Doñana Natural and National Parks is also significant.

Table 1 shows the synthesis of the area comprised of these management units. There are a total of 183 FMU with an area of 52,022 ha, most of which are owned by Ence. Of the total area, $74.68 \%$ (38,850.41 ha) is, on the whole, planted with Eucaliptus globulus Labill, for logging purposes, with the remaining $25.32 \%(13,172.32$ ha) covered by natural or semi-natural vegetation formations. These latter constitute the conservation areas and include grasslands, scrublands, rocky areas, forests or meadows of Quercus spp. Infrastructures such as firewalls or reservoirs, among others, can also be found, though to a lesser extent. Figure 2 shows one of the conservation areas that are generally comprised of river valleys, banks, rocks, meadows and remnants of the original sclerophyllous forest, in the eucalyptus matrix.

Our study focuses on the $25.32 \%$ comprised of conservation areas where the identification, assessment, maintenance and monitoring of HCVAs is mandatory in order to obtain FSC certification. Table 2 compares our methodology with the guidelines from the HCV Resource Network and FSC [14-16] in terms of identification, assessment and monitoring steps. 


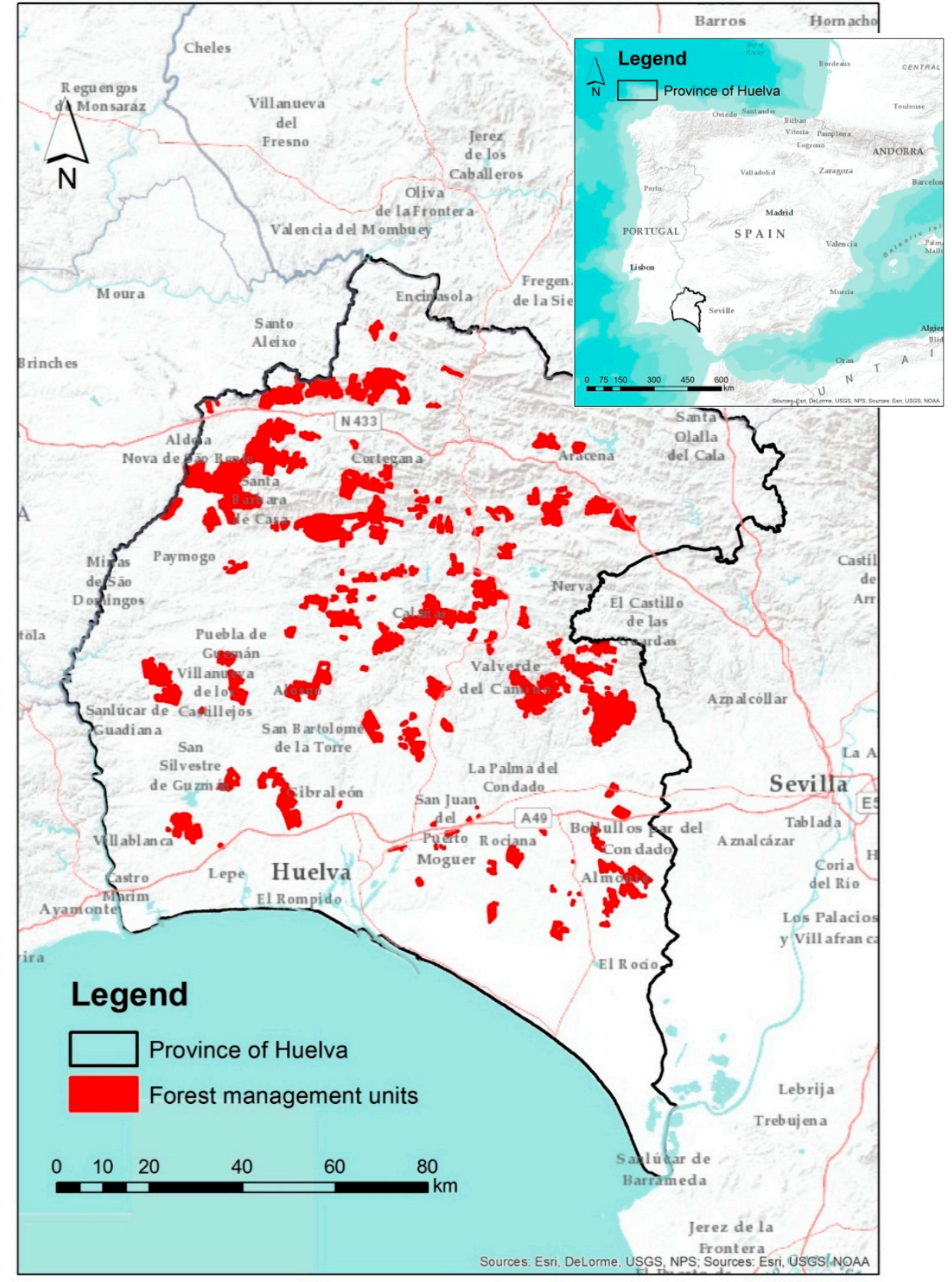

Figure 1. Location of Ence's forest management units (FMUs) in the province of Huelva.

Table 1. Summary of Ence's forest management units in the province of Huelva, including the total area of each eucalyptus species, other land uses (infrastructure, reservoirs, paths, firewalls, etc.) and conservation areas. Total surface expressed in bold.

\begin{tabular}{ccc}
\hline Land Uses & Area (ha) & \% \\
\hline Forest Management (ha) & $\mathbf{3 8 , 8 5 0 . 4 1}$ & $\mathbf{7 4 . 6 8}$ \\
Eucalyptus globulus Labill & $35,987.74$ & 69.18 \\
Eucalyptus maidenii F. Muell. & 1349.10 & 2.59 \\
Eucalyptus camaldulensis Dehnh. & 806.86 & 1.55 \\
Eucalyptus dunnii Maiden & 123.62 & 0.24 \\
Eucalyptus saligna Sm. & 47.00 & 0.09 \\
Other Eucalyptus spp. & 124.71 & 0.24 \\
Other land uses & 411.38 & 0.79 \\
Conservation Areas (ha) & $\mathbf{1 3 , 1 7 2 . 2 3}$ & $\mathbf{2 5 . 3 2}$ \\
Total Area (ha) & $\mathbf{5 2 , 0 2 2 . 6 4}$ & $\mathbf{1 0 0}$ \\
\hline
\end{tabular}




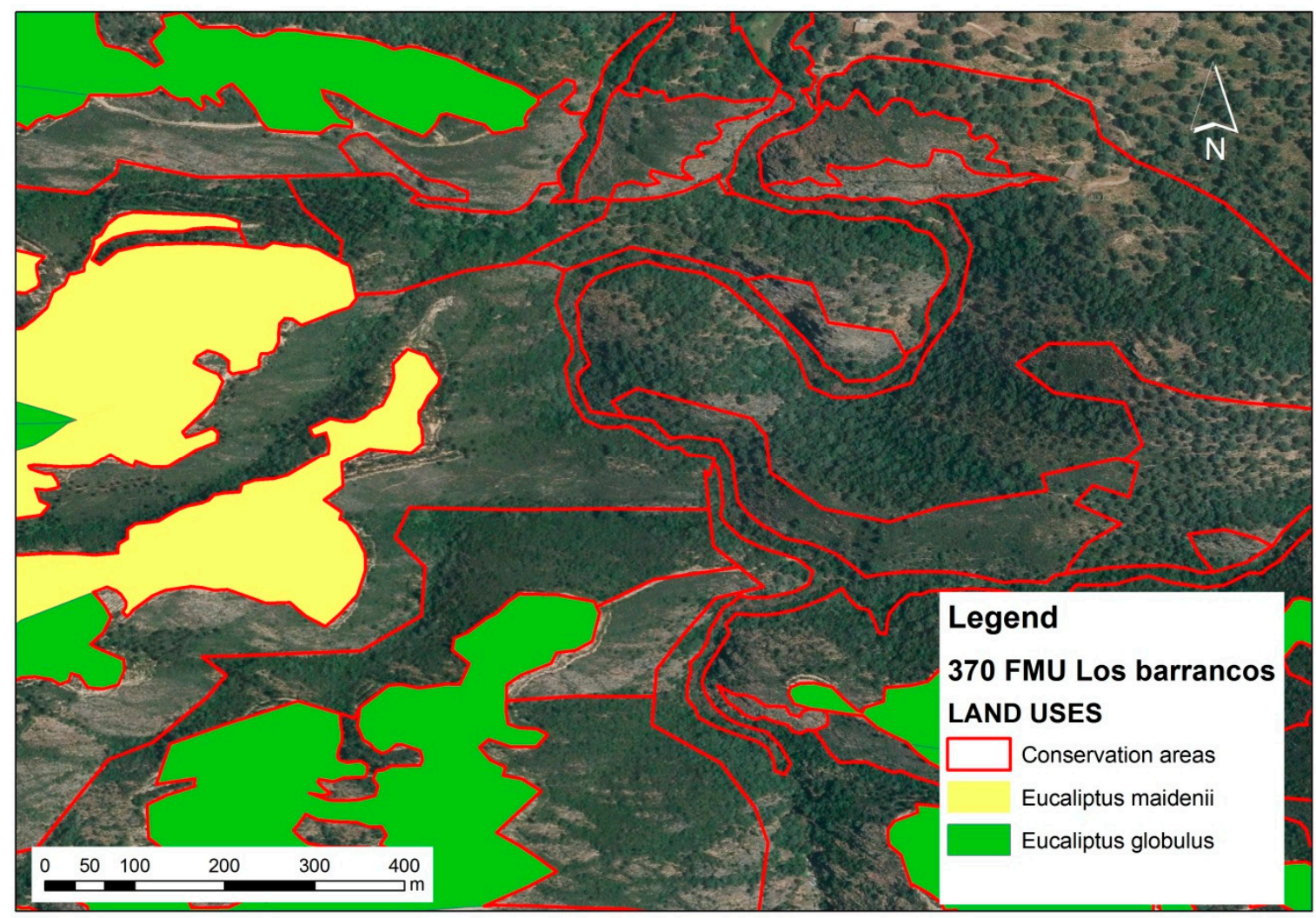

Figure 2. Digital orthophotograph of PNOA (Plan Nacional de Ortofotografía Aérea) with the shapefile of the Forest Management Unit (FMU) "Los Barrancos," located in the municipality of Aracena (Nature Park of Sierra de Aracena, Huelva, Spain). The polygons correspond to conservation areas of natural or semi natural vegetation. These areas are typically in a matrix of eucalyptus plantation, usually arranged into terraces, for logging purposes.

Table 2. Comparison between the methodology used in this study and the guidelines from the HCV Resource Network in terms of identification, assessment and monitoring steps.

\begin{tabular}{lccc}
\hline & $\begin{array}{c}\text { HCV Resource } \\
\text { Network: Common } \\
\text { Guidance for HCV } \\
\text { Identification }\end{array}$ & $\begin{array}{c}\text { HCV Resource Network: } \\
\text { Common Guidance for } \\
\text { Management and } \\
\text { Monitoring }\end{array}$ & $\begin{array}{c}\text { Methodology Used in } \\
\text { This Study }\end{array}$ \\
\hline Key terms and concepts & Yes & Yes & Yes \\
\hline Indicators and data sources & General & - & $\begin{array}{c}\text { Specific and ready to be } \\
\text { used by forest manager }\end{array}$ \\
\hline Case Study & - & Several, brief & One, thoroughly detailed \\
\hline $\begin{array}{l}\text { HCV Identification } \\
\text { methodology }\end{array}$ & - & - & $\begin{array}{c}\text { Yes, with specific } \\
\text { indicators ready to be } \\
\text { used. Based on Habitats } \\
\text { Directive- replicable in } \\
\text { other MUs and countries }\end{array}$ \\
\hline HCV assessment methodology & - & - & Yes \\
\hline HCV monitoring methodology & General & $\begin{array}{c}\text { Specific, based on } \\
\text { collected data }\end{array}$ \\
\hline
\end{tabular}

\subsection{Identification of HCVs in the Management Units}

Identification is carried out by means of the correspondence of the present habitats with those listed in Annex I of the Habitats Directive (Council Directive 92/43/EEC of 21 May 1992) [7], which includes all the Habitats of Community Interest (HCI) whose conservation requires the designation of special 
areas which comprise the Natura 2000 network. This list constitutes a European reference agreement resulting from a long process of interpretation using the Interpretation Manual of European Union Habitats [17] and phytosociology as the common methodological framework. Annex I currently lists 233 European natural habitat types arranged in categories based on a four digit code. It is divided into 9 main groups, from coastal habitats to forests, from which the first figure is taken. These groups are then arranged into subgroups, giving the second figure, before finally being subdivided into categories which constitute the last 2 figures of the EU code.

The Habitats Directive focuses on the conservation of habitats as the areas where both plant and animal species find a suitable environment to exist and grow. The directive also considers the relationship of such habitats with the people that depend on or benefit from them (in the case study area, some examples are apiculture, cork extraction or cattle pasture. In considering all of these aspects, the use of Annex I of the Habitats Directive allows for the identification of the different types of HCVs that can be found in a forest, as defined by FSC Principle 9 [7]. Specific criteria or emphasis on the proposed criteria can be included for those areas where the conservation of a species or culturally relevant areas requires more frequent monitoring. Stakeholder involvement is obligatory to obtain FSC certification, not only for the identification of HCVs but also to comply with other relevant FSC requirements and, as such, input from local representatives and institutions was sought and considered when implementing this methodology.

When a conservation area encompasses one or more habitats corresponding to the HCI listed in Annex I, it is considered a HCVA, as outlined in the FSC standard. Where a conservation area lacks correspondence and therefore has no HCVAs, it is still conserved according to the FSC standard but has a lower monitoring frequency. It is only HCVAs that will proceed to the assessment and monitoring phases and will be subject to more rigorous conservation measures. Our field study adopts the vegetation classification methodology proposed by Braun-Blanquet [18] and the Mueller-Dombois \& Ellenberg [19] approach to the location of forest inventories. In general, all the conservation areas are sampled by means of one or more of these phytosociological inventories, with phytosociological classification being based on available bibliography [20,21]. Phytosociological inventories are based on the characteristic species, which are species present only in a certain association or group of associations showing a marked preference for some ecological requirements and/or restricted distribution areas. The field work was conducted every spring (March-June approximately) in order to coincide with the maximum representation of the flora, fauna and vegetation in the habitats from 2012 to 2017 in all the forest management units. Infrastructures such as firewalls, reservoirs, ruins and so forth, were excluded in the prospection. Following the identification of the inventoried habitat, it was checked against the HCI listed in the Habitats Directive and, if correspondence was found, considered to be HCVA. In the exploration of the conservation areas, in addition to the habitat samples, threatened and invasive alien plant and animal species are also identified. The threatened species are defined in the applicable environmental regulations. In this case, the catalogue included in DECREE 23/2012 regulates the conservation and sustainable use of wild flora and fauna and their habitats in Andalusia [22], while exotic flora is regulated by Royal Decree 630/2013 [23]. A total of 4367 polygons have been prospected and 729 phytosociological inventories have been carried out. The final result, using digital cartography, is a detailed representation of all the conservation areas to scale 1:1000, with the associated inventories. These data and associated information were submitted to the subsequent phases.

\subsection{Assessment of the HCVs in the Management Units}

Once the HCIs have been identified and considered as HCVAs, the methodology for their assessment is established by means of the Habitats Directive scale, which is easily applicable based on the habitat's current state of conservation. Article 1 of the Habitats Directive 92/43/EEC [5] defines the conservation status of a natural habitat according to the sum of the influences acting on it and its typical species that may affect its long-term natural distribution, structure and functions as well as the long-term survival of its typical species within the territory. A conservation status is deemed 
"favourable" when its natural range and the areas covered within that range are stable or increasing, the specific structure and functions necessary for its long-term maintenance exist and are likely to continue to exist for the foreseeable future and the conservation status of its typical species is favourable. An "inadequate-unfavourable" state is assigned for situations where a change in management is necessary but where the danger of extinction is not very high. Finally, an "unfavourable-bad" conservation status corresponds to a habitat that is in serious danger of disappearing (at least locally). Applying this scale, HCIs in the conservation areas (HCVAs) can be evaluated according to a set of parameters related to the dynamism, structure and floristic composition of the habitat (Table 3):

Table 3. List of criteria used in the assessment phase. Description and parameters used for the proposed scale.

\begin{tabular}{|c|c|c|}
\hline Criteria & Description & Parameters \\
\hline $\mathbf{A}$ & $\begin{array}{l}\text { Current and potential area } \\
\text { within management unit }\end{array}$ & $\begin{array}{l}\text { Favourable: }>75 \% \text { of the potential surface } \\
\text { Unfavourable-inadequate: between } 30-75 \% \text { of the potential surface } \\
\text { Unfavourable-bad: occupies less than } 30 \% \text { of the potential surface }\end{array}$ \\
\hline B & $\begin{array}{c}\text { Minimum area and degree of } \\
\text { isolation }\end{array}$ & $\begin{array}{l}\text { FORESTS: Favourable: }>10 \text { ha. Unfavourable-inadequate: } 2-10 \text { ha. } \\
\text { Unfavourable-bad: }<2 \text { ha. } \\
\text { RIPARIAN: Favourable: }>2 \text { ha. Unfavourable-inadequate: } 0.5-2 \text { ha. } \\
\text { Unfavourable-bad: }<0.5 \text { ha. } \\
\text { SCRUBS: Favourable: }>5 \text { ha. Unfavourable-inadequate: } 2-5 \text { ha. } \\
\text { Unfavourable-bad: }<2 \text { ha. } \\
\text { PASTURES AND ROCKY AREAS: Favourable: }>2 \text { ha. } \\
\text { Unfavourable-inadequate: } 0.5-2 \text { ha. Unfavourable-bad: }<0.5 \text { ha. }\end{array}$ \\
\hline $\mathrm{C}$ & $\begin{array}{l}\text { Number of characteristic } \\
\text { species }\end{array}$ & $\begin{array}{l}\text { Based on identified species in the inventories in relation to the original } \\
\text { description of the community present in bibliography. } \\
\text { Favourable: all characteristics species are present. } \\
\text { Unfavourable-inadequate: } 1 \text { characteristic species is missing. } \\
\text { Unfavourable-bad: } 1 \text { or more characteristic species are missing. }\end{array}$ \\
\hline D & $\begin{array}{l}\text { Invasion of invasive alien } \\
\text { flora }\end{array}$ & $\begin{array}{l}\text { Degree of area affected and hazard level of the species detected } \\
\text { HIGH LEVEL: Favourable: }<1 \% \text {. Unfavourable-inadequate: } 1-10 \% \text {. } \\
\text { Unfavourable-bad: }>10 \% \text {. } \\
\text { MEDIUM LEVEL: Favourable: }<5 \% \text {. Unfavourable-inadequate: } 5-25 \% \text {. } \\
\text { Unfavourable-bad: }>25 \% \text {. } \\
\text { LOW LEVEL: Favourable: }<10 \% \text {. Unfavourable-inadequate: } 10-40 \% \text {. } \\
\text { Unfavourable-bad: }>40 \% \text {. }\end{array}$ \\
\hline E & $\begin{array}{l}\text { Presence of protected or } \\
\text { threatened plants }\end{array}$ & $\begin{array}{l}\text { Number of species and relative abundance. } \\
\text { Favourable: presence of viable populations. } \\
\text { Unfavourable-inadequate: presence of few or declined populations. } \\
\text { Unfavourable-bad: disappearance of previously known populations or } \\
\text { registered decline of more than } 50 \% \text {. }\end{array}$ \\
\hline $\mathbf{F}$ & Evidence of recent forest fires & $\begin{array}{l}\text { Favourable: There are no signs of fires. } \\
\text { Unfavourable-inadequate: Visible signs of past fires. } \\
\text { Unfavourable-bad: Recent and direct damages by fire }\end{array}$ \\
\hline
\end{tabular}

Each HCI in the conservation areas (HCVAs) is assessed according to these parameters in each Forest Management Unit, each one having the same relative weight. They can be "favourable," "inadequate-unfavourable" or "unfavourable-bad" depending on the corresponding criteria described in each parameter (Table 3). A conservation area is considered "favourable" when 4 or more parameters (A, B, C, D, E, F) are deemed as such, "unfavourable-inadequate" when only 2 or 3 meet the criteria and "unfavourable-bad" where there is only 1 or indeed no favourable parameters. This process runs parallel to the identification schedule and on completion of both, the results are submitted in a report to each Forest Management Unit. This report forms the basis for future strategy and management. In addition to these values, forest managers can establish several strategies necessary for the conservation of the HCVAs such as the promotion and conservation of native vegetation; silvicultural activities to improve the forests; eradication/control of invasive alien species; protection against grazing (fences); control/reduction of erosion processes; improvement of infrastructures; 
landscape improvement; revaluation of singular elements and so forth. This additional parameter, the results of which should be reviewed during the monitoring programme, is the responsibility of the company.

\subsection{Monitoring of the HCVAs in the Management Units}

Once assessed, the conservation areas can be maintained in their current status without any management. Nevertheless, with a view to guaranteeing the maintenance or improvement of their conservation status, the establishment of a monitoring protocol is recommended. This establishes a regular inspection of the area, the frequency of which is dependent on its characteristics. Given the high number of management units and conservation areas, this protocol is designed to prioritise the inspection of the most sensitive areas, which consequently have a greater need for attention. In practical terms, this means an increase in the frequency of the conservation area inspection. To prioritise the HCVA in a FMU, an assessment is conducted using seven parameters to diagnose the most sensitive areas. The parameters considered as priorities for conservation and therefore monitoring, have been grouped as follows:

1. Presence of Priority Habitats for the Habitats Directive (marked with an * in Annex I).

2. Presence of threatened flora.

3. Presence of Invasive species.

4. Global assessment of the state of conservation: based on the result obtained in the assessment phase. This parameter is considered when the FMU is assessed as "Unfavourable-bad"

5. Conservation actions (when some proposals were made in the assessment phase to promote the conservation).

6. Fragmentation of the habitat: Analysis of the habitat fragmentation through the Conefor 2.6 software (http:/ / www.conefor.org/). This methodology [24,25], based on graph theory, allows us to know the habitat availability and the state of fragmentation and isolation of each patch in the global matrix and the possibilities for connection and dispersion of species. A value is assigned to each habitat depending on its role in the connectivity. In this way, the software clearly identifies those habitats which are particularly isolated.

7. Technical Assessment: All the aforementioned parameters are easily assessed as they are based on objective and measured criteria. Nevertheless, there are certain habitats/circumstances where it is advisable to consider an additional criterion based on the opinion of experts in the area. Following a deep characterisation of the conservation areas, it was decided that the presence of mature forests or singular or infrequent elements in the area should be considered in this additional parameter. The presence of these elements, often relict, means they are of great interest in terms of conservation and maintenance is key to guaranteeing adequate management of the territory.

According to these parameters, each of the conservation areas is assigned a numerical value (value 0: negative diagnosis or evidence of the parameter and value 1: positive diagnosis or evidence of the parameter). The data obtained by each HCI in the HCVA in each management unit will be the final value used to establish the level of priority and the subsequent periodicity in the monitoring phase. Table 4 shows the frequency of the inspection (monitoring) of each habitat depending on the value of this assessment. Monitoring periods have been based on both the Habitats Directive (Article 17), which establishes that every 6 years an evaluation of the status of the HCI must be carried out and on Law 42/2007, of Natural Heritage and Biodiversity (Article 47) [26] which establishes a 3-year evaluation period for areas with endangered species and a 6-year period for the remaining threatened species. 
Table 4. Prioritisation level and monitoring frequency depending on the assessment value.

\begin{tabular}{ccc}
\hline Prioritization Level & Assessment Value & Monitoring Frequency \\
\hline 1 & $\geq 4$ & 3 years \\
2 & $2-3$ & 6 years \\
3 & $0-1$ & Monitoring not necessary \\
\hline
\end{tabular}

\section{Results}

\subsection{Identification of HCVAs}

The exploration of 13,583.27 ha of conservation areas has allowed us to identify a total of 11,847.45 ha of HCVA corresponding to HCIs, representing $22.77 \%$ of the total area of the forests managed by Ence (Table 5). The remaining areas not devoted to forest management are covered by several types of vegetation, the majority being serial scrubs (rockroses and gorses), with pastures, pine plantations (Pinus pinea and Pinus pinaster) and abandoned eucalyptus plantations also frequently in evidence. As these types of vegetation are not included in Annex I of the Habitats Directive, they are not considered as HCVAs. In total, these non-HCVAs represent 1735.32 ha (3.34\%). A total of 19 different types of HCIs in the HCVA have been identified (Table 5), the most widespread being heathlands, belonging to Group 4 (temperate heath and scrub) of the Habitats Directive, followed by Group 9 (forests). These are also the most frequent (Table 5) although many of them are relicts with limited extension.

Table 5. Area of the different types of HCI in the conservation areas of the Spanish province of Huelva and number of patches and summary of the assessment of all habitats managed by Ence in the province of Huelva. Sorted by type and subtype as established in Annex I of the Habitats Directive. The habitats that appear with an asterisk $\left({ }^{*}\right)$ are considered priorities for the EU. Total number of patches and area are expressed in bold.

\begin{tabular}{|c|c|c|c|c|c|}
\hline \multirow{2}{*}{ EU Habitat Type } & \multirow{2}{*}{$\begin{array}{c}\text { N } \\
\text { Patches }\end{array}$} & \multirow{2}{*}{$\begin{array}{l}\text { AREA } \\
\text { (ha) }\end{array}$} & \multicolumn{3}{|c|}{ Unfavourable } \\
\hline & & & Favourable & Inadequate & Bad \\
\hline 2 Coastal Sand Dunes and Inland Dunes & 4 & 8.35 & & & \\
\hline 2260. Cisto-Lavenduletalia dune sclerophyllous scrubs & 4 & 8.35 & 4 & 0 & 0 \\
\hline 3 Freshwater Habitats & 15 & 97.87 & & & \\
\hline $\begin{array}{l}\text { 3110. Oligotrophic waters containing very few minerals of sandy plains } \\
\text { (Littorelletalia uniflorae) }\end{array}$ & 10 & 69.12 & 10 & 0 & 0 \\
\hline $\begin{array}{l}\text { 3150. Natural eutrophic lakes with Magnopotamion or Hydrocharition-type } \\
\text { vegetation }\end{array}$ & 5 & 28.75 & 5 & 0 & 0 \\
\hline 4 Temperate Heath and Scrub & 123 & 4981.56 & & & \\
\hline 4020. ${ }^{*}$ Temperate Atlantic wet heaths with Erica ciliaris and Erica tetralix & 3 & 1.18 & 2 & 1 & 0 \\
\hline 4030. European dry heaths & 120 & 4980.38 & 120 & 0 & 0 \\
\hline 5 Sclerophyllous Scrub (Matorral) & 148 & 1619.13 & & & \\
\hline $\begin{array}{l}\text { 5110. Stable xerothermophilous formations with Buxus sempervirens on rock } \\
\text { slopes (Berberidion p.p.) }\end{array}$ & 8 & 27.41 & 8 & 0 & 0 \\
\hline 5330. Thermo-Mediterranean and pre-desert scrub & 140 & 1591.72 & 128 & 12 & 0 \\
\hline 6 Natural and Semi-Natural Grassland Formations & 125 & 1476.82 & & & \\
\hline 6220. * Pseudo-steppe with grasses and annuals of the Thero-Brachypodietea & 48 & 650.63 & 48 & 0 & 0 \\
\hline 6310. Dehesas with evergreen Quercus spp. & 46 & 654.94 & 46 & 0 & 0 \\
\hline $\begin{array}{l}\text { 6410. Molinia meadows on calcareous, peaty or clayey-silt-laden soils } \\
\text { (Molinion caeruleae) }\end{array}$ & 16 & 41.95 & 15 & 1 & 0 \\
\hline 6420. Mediterranean tall humid grasslands of the Molinio-Holoschoenion & 15 & 129.30 & 15 & 0 & 0 \\
\hline 8 Rocky Habitats and Caves & 112 & 1302.08 & & & \\
\hline 8220. Siliceous rocky slopes with chasmophytic vegetation & 107 & 1277.18 & 107 & 0 & 0 \\
\hline $\begin{array}{l}\text { 8230. Siliceous rock with vegetation of the Sedo-Scleranthion or Sedo } \\
\text { albi-Veronicion dillenii }\end{array}$ & 5 & 24.9 & 5 & 0 & 0 \\
\hline 9 Forests & 268 & 2361.64 & & & \\
\hline 91B0. Thermophilous Fraxinus angustifolia woods & 13 & 33.55 & 13 & 0 & 0 \\
\hline $\begin{array}{l}\text { 91E0. * Alluvial forests with Alnus glutinosa and Fraxinus excelsior (Alno-Padion, } \\
\text { Alnion incanae, Salicion albae) }\end{array}$ & 11 & 9.19 & 11 & 0 & 0 \\
\hline 92A0. Salix alba and Populus alba galleries & 13 & 10.53 & 9 & 4 & 0 \\
\hline $\begin{array}{l}\text { 92D0. Southern riparian galleries and thickets (Nerio-Tamaricetea and } \\
\text { Securinegion tinctoriae) }\end{array}$ & 140 & 715.51 & 137 & 3 & 0 \\
\hline 9330. Quercus suber forests & 40 & 1056.91 & 34 & 5 & 1 \\
\hline 9340. Quercus ilex and Quercus rotundifolia forests & 51 & 535.95 & 40 & 11 & 0 \\
\hline Total & 795 & $11,847.45$ & & & \\
\hline
\end{tabular}


The Appendix A shows the correspondence of each HCI with the phytosociological community described in the European Union Interpretation Manual. Group 4-Heath, is primarily represented by a unique habitat type: 4030-European dry heath. This is largely comprised of the rockrose-heathlands of the species Erica australis L., which constitutes the subassociation ericetosum australis of the association of Genisto hirsutae-Cistetum ladaniferi and of Ulici eriocladi-Cistetum ladaniferi, though priority heaths (Group 4020-temperate Atlantic wet heath) are relicts which can also found in the area. Group 5-Sclerophyllous shrubs, is mainly represented by habitat 5330-Thermo-Mediterranean shrubs, which are represented by the genus arbutus (Phillyreo angustifoliae-Arbutetum unedonis), dominated by the species Arbutus unedo L., Erica arborea L. or Phillyrea angustifolia L. Other Thermo-Mediterranean scrublands are represented by Asparago albi-Rhamnetum oleoidis, with the xerophilous species Olea europaea var. sylvestris (Mill.) Lehr, Pistacia lentiscus L., Quercus coccifera L., Myrtus communis L. and Asparagus albus (L.) Thunb. It is also possible to identify some chasmophytic communities of Genistetum polyanthi, or broomlands in degraded areas dominated by the species Retama sphaerocarpa (L.) Boiss. From Group 6-Natural and Semi-natural Herbaceous Formations, a unique habitat, very abundant in the local agro-forestry farms, maintaining excellent semi-natural holm and cork-oak forests, is highlighted: 6310—Dehesas with evergreen Quercus spp. This particular habitat is an open oak forest combined with natural pasture for livestock. This type of traditional farming is considered an excellent example of the sustainable use of natural resources, where domestic animals (porcine, ovine and bovine) are fed by acorns and pasture in a natural landscape of high environmental value. The most abundant vegetation in Group 9 is represented by Southern riparian galleries and thickets (92D0), which corresponds to the blackberry-oleander community (Rubo ulmifolii-Nerietum oleandri) in the area, a riparian scrubland very common in temporal or ephemeral streams.

\subsection{Assessment of HCVs in HCVAs}

Following the identification of all the HCVAs and their corresponding HCI, evaluation was carried out for each management unit, considering the global conservation status of all the habitats of the same category. This assessment is summarised in the last three columns of Table 4 , which shows the majority to be "favourable," with some classified as "unfavourable-inadequate" due to the scant area of the patches (criterion A) and degree of isolation (criterion B). In some cases, the inventories highlighted the absence of some characteristic species (criterion C), possibly due to the degraded status of the plant community. On only one occasion was a management unit classified as "unfavourable-bad," with the HCVA in question being a highly degraded and isolated patch of cork-oak forest (9330) that was considered a relict representation of the area's climax vegetation. One group frequently classified as "unfavourable-inadequate" was Thermo-Mediterranean and pre-desert scrub (5330), a very common scrubland in the conservation areas, though on many occasions represented as an isolated group of a few individuals. Of all the groups, Group 9 was deemed the most "unfavourable-inadequate."

\subsection{Monitoring of HCVAs}

Once all the HCVAs in all the forest management units have been identified and assessed, it is possible to apply a monitoring programme to determine the frequency of habitat inspection. This ensures that the most sensitive areas are identified and subsequently reviewed with greater frequency. With respect to the first criterion (1, presence of Priority Habitats), three were identified: $91 E 0^{*}, 4020^{*}, 6620^{*}$ (see Table 4 for the description of the EU code and Appendix A for the corresponding phytosociological community). The first are Holartic riparian forests (Alnus glutinosa (L.) Gaertn.), the second relict Atlantic heathlands, very scarce in the area and the third pseudo-steppe grassland represented by several communities (see Appendix A for more details). In relation to the second criterion (2, presence of threatened flora), the following endangered species, listed in the national and regional regulations, were identified: Armeria velutina Boiss. \& Reut. (4 patches), Asplenium billotii F.W. Schultz (45 patches), Dianthus hinoxianus Gallego (2 patches), Erica andevalensis Cabezudo 
\& Rivera (12 patches), Isoetes durieui Bory (13 patches), Loeflingia baetica Lag. (1 patch) and Spiranthes aestivalis (Poir.) Rich. (1 patch). The third criterion (3, presence of invasive species), detected the following: Acacia dealbata Link., (4 patches), Agave americana L. (3 patches), Ailanthus altissima (Mill.) Swingle, (1 patch), Cylindropuntia subulata (Muehlenpf.) F.M. Knuth, (1 patch), Opuntia dillenii (Ker Gawl.) Haw., (3 patches), Opuntia maxima Mill. (1 patch) and Oxalis pes-caprae L. (23 patches). Criteria four (4, assessment of the state of conservation) and five (5, Conservation actions) deal with the results of the assessment phase and the proposed strategies to improve the conservation status of the area. Over all, few patches needed action, which, when required, was mainly focused on reducing pressure from livestock. Following analysis by Conefor 2.4 (criterion 6, fragmentation of the habitat), a total of 52 patches have been considered as highly fragmented belonging to the following HCI: 4020 (3 patches), 4030 (4 patches), 5110 (1 patch), 5330 (12 patches), 91B0 (5 patches), 91E0 (2 patches), 92A0 (6 patches), 92D0 (7 patches), 9330 (6 patches) and 9340 (6 patches). Criterion number seven (7, technical assessment) is the most conflictive, requiring the aid of a habitat expert. It was decided to include mature forests and singular and relict plant communities in this criterion, allowing for the inclusion of a total of 132 patches:

- Forests and edaphoclimatic communities:

- Thermo-Mediterranean Holm oak forests (Myrtus communis-Quercetum rotundifoliae), 17 patches.

- Meso-Mediterranean Holm oak forests (Pyro bourgaeanae-Quercetum rotundifoliae), en 35 rodales.

- $\quad$ Thermo-Mediterranean Cork oak forests (Myrto communis-Quercetum suberis), 11 patches.

- $\quad$ Meso-Mediterranean Cork oak forests (Sanguisorbo hybridae-Quercetum suberis), 28 patches.

- $\quad$ Riparian Alder forests (Scrophulario scorodoniae-Alnetum glutinosae), 11 patches.

- Singular or infrequent habitats in the study area:

- $\quad$ Riparian Red willow (Viti viniferae-Salicetum atrocinereae), 7 patches.

- $\quad$ Riparian Pedicel willow (Nerio oleandri-Salicetum pedicellatae), 1 patch.

- $\quad$ Heath (Erico ciliaris-Ulicetum minoris), 3 patches.

- $\quad$ Reed bed (Juncetum rugoso-effusi), 16 patches.

- $\quad$ Riparian elm forests (Aro italici-Ulmetum minoris), 1 patch.

- $\quad$ Mine heather (Junco rugosi-Ericetum andevalensis), 2 patches.

After evaluating all the criteria established in the monitoring protocol, a total of 91 patches from HCVAs were considered as priority candidates for more frequent monitoring. Of these patches, 5 obtained prioritisation level 1 with inspection proposed every 3 years and 86 obtained prioritisation level 2 with inspection every 6 years (Table 6).

Table 6. Prioritisation levels and number of patches of each level.

\begin{tabular}{cccc}
\hline Prioritization Level & Assessment Value & Monitoring Period & Number of Patches \\
\hline 1 & $\geq 4$ & 3 years & 5 \\
2 & $2-3$ & 6 years & 86 \\
3 & $0-1$ & Monitoring not necessary & 704 \\
\hline
\end{tabular}

Classification of the most critical patches (level 1) is shown in Table 7. It is interesting to point out that all relict Atlantic heaths (4020 UE code), present in three different forest management units, were awarded the worst conservation status and therefore considered critically endangered. A thermo-Mediterranean holm oak forest (9340 UE code) and one of the three riparian thickets (92D0 UE code) composed of tamarisk were also awarded an unfavourable conservation status, which shows serious deficiencies in conservation terms. 
Table 7. Patches with prioritization level 1 and values assigned for each criterion.

\begin{tabular}{|c|c|c|c|c|c|c|c|c|c|c|}
\hline \multirow[b]{2}{*}{ Management Unit } & \multirow[b]{2}{*}{ Habitat Type } & \multirow[b]{2}{*}{ Community } & \multicolumn{8}{|c|}{ Criteria for Prioritization } \\
\hline & & & 1 & 2 & 3 & 4 & 5 & 6 & 7 & Result \\
\hline 316-EL BONAL & $\begin{array}{l}\text { 4020* Temperate Atlantic wet heaths with } \\
\text { Erica ciliaris and Erica tetralix }\end{array}$ & $\begin{array}{l}\text { Erico ciliaris-Ulicetum } \\
\text { minoris }\end{array}$ & 1 & 0 & 0 & 0 & 1 & 1 & 1 & 4 \\
\hline 334-PALLARES & $\begin{array}{l}4020 * \text { Temperate Atlantic wet heaths with } \\
\text { Erica ciliaris and Erica tetralix }\end{array}$ & $\begin{array}{l}\text { Erico ciliaris-Ulicetum } \\
\text { minoris }\end{array}$ & 1 & 0 & & 0 & 1 & 1 & 1 & 4 \\
\hline $\begin{array}{l}\text { 525-ALQUERIA } \\
\text { DEL POZO }\end{array}$ & $\begin{array}{l}9340 Q u e r c u s \text { ilex and Quercus rotundifolia } \\
\text { forests }\end{array}$ & $\begin{array}{l}\text { Myrto communis-Quercetum } \\
\text { rotundifoliae }\end{array}$ & 0 & 0 & 0 & 1 & 1 & 1 & 1 & 4 \\
\hline 539-LA GIRALDA & $\begin{array}{l}4020 * \text { Temperate Atlantic wet heaths with } \\
\text { Erica ciliaris and Erica tetralix }\end{array}$ & $\begin{array}{l}\text { Erico ciliaris-Ulicetum } \\
\text { minoris }\end{array}$ & 1 & 0 & & 1 & 0 & 1 & 1 & 4 \\
\hline 667-ALGARROBO & 92D0 Southern riparian galleries and thickets & $\begin{array}{l}\text { Polygono-Tamaricetum } \\
\text { africanae }\end{array}$ & 0 & 0 & 1 & 1 & 1 & 1 & 0 & 4 \\
\hline
\end{tabular}

\section{Discussion}

This methodology has proven being highly-effective in the evaluation, conservation and monitoring of conservation areas within timber harvesting zones and in helping Ence achieve FSC sustainable forest certification in Spanish forests [27]. It helps implement the FSC standard by providing clear, objective criteria, particularly for FSC Principle 9 [7], which defines a realistic evaluation and monitoring protocol applicable to any forest management system.

This study demonstrates that a forestry company can implement an objective and reliable methodology for identification, assessment and monitoring of HCVs. In this case, the FSC principles are widely upheld and sustainable management is compatible with the preservation of High Conservation Values Areas. The incorporation of this methodology into the global management of the Ence forestry management ensures the maintenance of biodiversity in the different forest management units. It is a lengthy process and the methodology required the aid of a group of experts (academic in this case). It is well-known that a long and complex certification process is a critical challenge that provokes "stakeholder fatigue" due to lack of perceived progress [6]. However, upon completion of the identification and assessment phases, the implementation of a monitoring strategy is easily developed using the techniques employed by the company, allowing the strategy to be maintained indefinitely.

The most time-consuming phase of this study was the identification of the habitats in the conservation areas, requiring 2-3 days a week of spring field study over a 5-year period. Every single patch was visited and inventory of the vegetation carried out when necessary. The identification of all of the habitats and subsequent establishment of their correspondence with the EU codes has led to the creation of a new and powerful conservation tool in the shape of a highly-detailed digital map to scale (1:1000). The representation of the conservation areas in this way assists in the planning and implementation of silvicultural activities in a way which is compatible with the preservation of the natural habitats. Furthermore, the information recovered during the identification phase is transcribed into a technical report for each forest management unit, which is made available to all the workers involved. In this way, the managers of each unit have the same detailed information of both the eucalyptus plantation and the conservation areas. This equilibrium is a milestone in sustainable development. Financial feasibility depends largely on the company's strategy, though its size might also be a relevant factor to take into consideration. In the case of ENCE, the size of their forest $(52,022.64 \mathrm{ha})$ and the management objectives justify the time and resources invested in the assessment and monitoring, through the establishment of a specific fieldwork team. In their case, the cost-benefit analysis results are positive as this methodology guarantees the compliance with the HCV and the conservation area network requirements established by FSC. Certified products are highly competitive in the national and international markets, helping compensate for the costs incurred. Indeed, in some cases, the market does not accept non-certified products, or FSC certification is required for public procurement.

Biodiversity, sustainable development, nature conservation and so forth, are fundamental issues nowadays. All companies, administrations, governments and international organizations pay increasing attention to biodiversity conservation and sustainability due to social pressure. 
Medium/large companies focused on natural resource management that fail to keep pace with this unstoppable trend are meet with societal disdain. From the FSC certification viewpoint, this assessment helps Ence to comply with FSC requirements and to identify and characterise its entire conservation area network. Furthermore, additional potential sources of income, such as payments for ecosystem services based on the newly-released FSC Ecosystem Services Procedure [28], provide additional motivation to continue implementing and monitoring the methodology.

Governments (European, National and Regional) are responsible for the maintenance of the biodiversity of their territories. The most ambitious initiative was that promoted by the European Union (Habitats Directive) with the aim of creating a coherent ecological network, known as Natura 2000 [29]. This network is already in operation and has proven to be an excellent global conservation strategy. Forests in Natura 2000 can be managed with a view to achieving multiple functions, such as timber production, hunting and recreation, in addition to nature protection [30]. Nevertheless, it was recently reported that more efforts are needed in order for this network to reach its full potential [31]. Although the Natura 2000 network helps to tackle a broad range of biodiversity problems [4], there remain some unresolved issues; the vaguely defined concept of a forest habitat type, the conservation status of a forest habitat type, the lack of defined indicators of conservation status and undeveloped concepts for the stewardship of forest habitat types, to name a few. However, the compatibility between forest management and conservation proposed by this network encouraged us to use their methodology for the identification and classification of the High Conservation Values defined in Principle 9 of FSC's forest certification. This classification of HCIs has been widely applied to all the natural habitats of the member states with a high degree of replicability everywhere it has been implemented. This process has allowed us to identify numerous different habitats, many of them endangered or relict, with high accuracy and with the full backing of the European Environmental Agency (EEA). We have identified a wide range of the habitats listed in Annex 1. Indeed, with the exception of groups 1 (coastal and halophytic habitats) and 7 (raised bogs and mires and fens), which are logically absent from this geographical area, at least one representation of the rest of the habitat groups listed in Annex 1 have been detected. It is interesting to note that the habitats most highly represented in the conservation areas are those of Group 9 (Forests), with a total of 6 subtypes. This group in the most striking in terms of ecological succession because it is representative of the woodland vegetation native to the territory (in both riparian and dry land areas). In total, 19 subtypes of EU habitats, represented by 48 different phytosociological communities, have been detected. This result shows a higher level of biodiversity than the most representative protected area in the study zone, the Natural Park of Sierra de Aracena y Picos de Aroche, which has 186,795.16 ha and only 16 subtypes [32]. With respect to priority habitat, we have found a total of 8 out of 48 communities, representing one sixth of the total $(16.6 \%)$. In conclusion, the tandem FSC-Habitats Directive has demonstrated to be an interesting initiative to be considered in other forest areas and even in protected sites.

One of the main objective criteria for the identification of the HCVs of FSC principle 9 is their correspondence with Annex I of the Habitat Directive. Outside the European Union, the availability of data is scarce, as are regulations. However, not only could this methodology be implemented within any other EU country but it could also be easily applied to non-EU countries by substituting this fundamental criterion for another international classification, perhaps less exhaustive than that of the EU but still environmentally acceptable. In this context we propose the Red List of Ecosystems [33], put forward by the International Union for Conservation of Nature (IUCN), as an alternative to Annex I of the Habitats Directive. An interesting classification and assessment of this list that could be applied to our methodology as the main criteria for the identification and assessment of HCVs is already available.

In conclusion, despite the highly time-consuming nature of the process, our methodology has demonstrated a high degree of accuracy in the location and characterization of interesting and representative habitats in the conservation areas, as evidenced by the discovery of new localities 
of endangered flora [34-36] one of which (Narcissus scaberulus Henriq.) is listed in Annex II of the Habitats Directive. Furthermore, it is the first recorded in Western Andalusia.

The assessment phase, using 6 objective criteria (A-F), also proved a successful tool in the evaluation of the conservation status of the habitats, being both easy and quick to apply following identification of the habitat. The proposed scale being the same as that used in habitat assessment by the EU ensures that our results are compatible with theirs. However, our approach takes things a step further by evaluating the $\mathrm{HCI}$ by forest management unit rather than by Special Conservation Area (SCA, the areas included in the Natura 2000 Network) as per the EU approach. This results in a level of detail that aids in the management and maintenance of the biodiversity with even greater accuracy. The application of this methodology has revealed that the conservation status of the areas under study was higher than initially expected. Fortunately, few HCVAs were assessed as "unfavourable-bad." Group 9, on the whole highly representative of the native Mediterranean forests [37] was the worst evaluated, with 24 HCVAs in the different FMUs classified as "unfavourable." These relict forest formations are only maintained in a small number of enclaves, the degree of isolation of these patches and the intensity of edge-effect leading to a deficient conservation status. In any case, the effectiveness of the proposed methodology is evidenced by its ability to identify these critical areas, which will subsequently be submitted for a priority re-evaluation process in order to improve their conservation measures.

The methodology tested in the monitoring strategy utilized a coherent and straightforward set of criteria (1-7) using all the information obtained in the previous steps. All priority habitats, endangered and invasive alien species and isolated patches were detected and considered in the evaluation. The results highlighted those critical patches in need of more frequent inspection in order to meet the requirements of FSC certification. Using this strategy, it is possible to maintain control of all conservation areas and to reverse the negative conservation status of the most critical. With the aim of considering additional objective criteria, the 7th criterion (technical assessment) proved an interesting contribution to the final monitoring program. The inclusion of this criterion meant that even the most singular and representative habitats were considered, even if they had been positively evaluated in the assessment phase, thus giving these areas the significance they deserve.

Furthermore, this methodology has been included in the testing phase of the newly-released FSC Ecosystem Services Procedure [28]. This procedure provides a series of steps to demonstrate the positive impacts of FSC-certified forest management on ecosystem services. Through the identification and assessment of the conservation areas, the described methodology played a crucial role in demonstrating the positive impact of Ence's certified forest management on the conservation of biological diversity. The methodology was useful to measure several of the outcome indicators needed to prove the sufficiency of the conservation areas for the maintenance of biodiversity and helped implement the Ecosystem Services Procedure. The certification body participating in the pilot test agreed as well that this methodology was useful to demonstrate the positive impact that FSC-certified forest management has on ecosystem services, particularly on the conservation of biodiversity in this case.

\section{Conclusions}

The objective of this study has been broadly reached. The methodology guarantees the identification, maintenance and improvement of biodiversity in forest management and helps meet the sustainable forestry requirements established by FSC.

Due to its objectivity, this strategy can be easily applied to other forest management sites in Europe. In order to establish whether this methodology could be applied to countries outside Europe, compatibility with other conservation strategies should be tested. In any case, the proposed strategy could at least serve as a preliminary working scheme in those countries. 
Author Contributions: Conceptualization, R.G., P.J.H.; Funding acquisition, P.J.H.; Investigation, A.J.S.-A., P.J.H., J.M.C. and J.L.-T.; Project administration, J.M.C.; Resources, J.M.C.; Supervision, P.J.H.; Validation, R.G. and J.M.C.; Writing—original draft, A.J.S.-A.; Writing—review \& editing, P.J.H., R.G. and J.L.-T.

Funding: This research was funded by ENCE, Energía y Celulosa by the contract with the Department of Integrated Sciences, University of Huelva entitled: Identificación y Caracterización de Hábitats de Interés Comunitario en los Montes Gestionados por Ence, Energía y Celulosa en la Zona Sur, fases I, II, III y IV.

Acknowledgments: Authors are grateful to overseers of the Forests Management Unit for their help in accessing to the forests and natural areas.

Conflicts of Interest: The authors declare no conflict of interest.

\section{Appendix A}

\begin{tabular}{|c|c|c|c|}
\hline EU Code & Community & $\mathbf{N}^{\circ}$ Patches & AREA (ha) \\
\hline 2260 & Halimio halimifolii-Stauracanthetum genistoidis & 4 & 8.40 \\
\hline \multirow[t]{2}{*}{3110} & Scirpo fluitantis-Juncetum heterophylli & 10 & 69.10 \\
\hline & Lemnetum minoris & 1 & 1.90 \\
\hline \multirow[t]{2}{*}{3150} & Lemnetum gibbae & 1 & 14.70 \\
\hline & Callitricho stagnalis-Ranunculetum saniculifolii & 3 & 12.10 \\
\hline \multirow[t]{2}{*}{$4020^{*}$} & Erico ciliaris-Ulicetum minoris & 3 & 1.20 \\
\hline & Erico australis-Cistetum populifolii & 4 & 360.76 \\
\hline \multirow{3}{*}{4030} & Genisto hirsutae-Cistetum ladaniferi subas. ericetosum australis & 25 & 1081.98 \\
\hline & Halimio ocymoidis-Ericetum umbellatae & 41 & 1946.28 \\
\hline & Ulici eriocladi-Cistetum ladaniferi subas. ericetosum australis & 50 & 1591.36 \\
\hline \multirow[t]{2}{*}{5110} & Lonicero hispanicae-Rubetum ulmifolii & 8 & 27.41 \\
\hline & Retamo sphaerocarpae-Cytisetum bourgaei & 4 & 14.88 \\
\hline \multirow{5}{*}{5330} & Genistetum polyanthi & 25 & 123.07 \\
\hline & Phillyreo angustifoliae-Arbutetum unedonis & 52 & 742.09 \\
\hline & Asparago albi-Rhamnetum oleoidis & 59 & 711.68 \\
\hline & Trifolio subterranei-Poetum bulbosae & 2 & 15.87 \\
\hline & Pulicario paludosae-Agrostietum porretii & 5 & 25.27 \\
\hline \multirow{4}{*}{$6220^{*}$} & Paronychio cymosae-Pterocephaletum diandri & 6 & 132.44 \\
\hline & Gaudinio fragilis-Agrostietum castellanae & 7 & 20.08 \\
\hline & Trifolio cherleri-Plantaginetum bellardi & 13 & 261.47 \\
\hline & Dauco criniti-Hyparrhenietum sinaicae & 15 & 195.50 \\
\hline \multirow{2}{*}{6310} & Dehesa of Quercus suber & 18 & 74.48 \\
\hline & Dehesa of Quercus ilex & 28 & 580.46 \\
\hline \multirow[t]{2}{*}{6410} & Juncetum rugoso-effusi & 16 & 41.95 \\
\hline & Junco rugosi-Ericetum andevalensis & 2 & 3.25 \\
\hline \multirow[t]{4}{*}{6420} & Holoschoeno-Juncetum acuti & 3 & 21.06 \\
\hline & Trifolio resupinati-Holoschoenetum & 10 & 104.99 \\
\hline & Polypodietum serrati & 2 & 4.03 \\
\hline & Cheilantho maderensis-Cosentinietum velleae & 10 & 88.37 \\
\hline \multirow[t]{3}{*}{8220} & Coincyo longirostrae-Dianthetum lusitani & 14 & 125.25 \\
\hline & Asplenio billotii-Cheilanthetum hispanicae & 39 & 616.98 \\
\hline & Selaginello denticulatae-Anogrammetum leptophyllae & 42 & 442.55 \\
\hline 8230 & Sedetum caespitoso-arenarii & 5 & 24,90 \\
\hline 1B0 & Ficario ranunculoidis-Fraxinetum angustifoliae & 13 & 33.55 \\
\hline 91E0* & Scrophulario scorodoniae-Alnetum glutinosae & 11 & 9.19 \\
\hline \multirow{7}{*}{ 92A0 } & Crataego brevispinae-Populetum albae & 1 & 0.11 \\
\hline & Nerio oleandri-Populetum albae & 1 & 0.39 \\
\hline & Nerio oleandri-Salicetum pedicellatae & 1 & 0.58 \\
\hline & Aro italici-Ulmetum minoris & 1 & 3.25 \\
\hline & Salici pedicellatae-Populetum albae & 2 & 0.95 \\
\hline & Viti viniferae-Salicetum atrocinereae & 7 & 5.25 \\
\hline & Polygono equisetiformis-Tamaricetum africanae & 3 & 1.83 \\
\hline \multirow[t]{2}{*}{ 92D0 } & Pyro bourgaeanae-Flueggeetum tinctoriae & 14 & 26.42 \\
\hline & Rubo ulmifolii-Nerietum oleandri & 123 & 687.26 \\
\hline \multirow{2}{*}{9330} & Myrto communis-Quercetum suberis & 11 & 361.65 \\
\hline & Sanguisorbo agrimonioidis-Quercetum suberis & 28 & 693.94 \\
\hline \multirow{2}{*}{9340} & Myrto communis-Quercetum rotundifoliae & 17 & 196.13 \\
\hline & Pyro bourgueanae-Quercetum rotundifoliae & 34 & 339.82 \\
\hline
\end{tabular}




\section{References}

1. Mayer, P. Hot Spot: Forest policy in Europe: Achievements of the MCPFE and challenges ahead. For. Policy Econ. 2000, 1, 177-185. [CrossRef]

2. Gomez-Zamalloa, M.G.; Caparros, A.; Ayanz, A.S. 15 years of Forest Certification in the European Union. Are we doing things right? Forest Syst. 2011, 20, 81-94. [CrossRef]

3. Barbati, A.; Marchetti, M.; Chirici, G.; Corona, P. European Forest Types and Forest Europe SFM indicators: Tools for monitoring progress on forest biodiversity conservation. For. Ecol. Manag. 2014, 321, 145-157. [CrossRef]

4. Kovac, M.; Kutnar, L.; Hladnik, D. Assessing biodiversity and conservation status of the Natura 2000 forest habitat types: Tools for designated forestlands stewardship. For. Ecol. Manag. 2016, 359, 256-267. [CrossRef]

5. Directive, H. Council Directive 92/43/EEC of 21 May 1992 on the conservation of natural habitats and of wild fauna and flora. OJ L 1992, 206, 7-50.

6. Hagan, J.M.; Whitman, A.A. Biodiversity Indicators for Sustainable Forestry: Simplifying Complexity. J. For. 2006, 104, 203-210.

7. Forest Stewardship Council A.C. FSC Principles and Criteria for Forest Stewardship (FSC-STD-01-001). 2015. Available online: https:/ /ic.fsc.org/en/what-is-fsc-certification/principles-criteria (accessed on 1 July 2018).

8. Ozinga, S. Behind the Logo: An Environmental and Social Assessment of Forest Certification Schemes; Forests and the European Resource Network: Moreton-in-Marsh, UK, 2001; pp. 1-64.

9. Clark, M.R.; Kozar, J.S. Comparing sustainable forest management certifications standards: A meta-analysis. Ecol. Soc. 2011, 16, 3. Available online: http://www.ecologyandsociety.org/vol16/iss1/art3 (accessed on 1 July 2018). [CrossRef]

10. Vegas, M.J.H. Largest forest biomass fired 50 Mwe power plant in south of Europe. In Proceedings of the 22nd European International Biomass Conference-Setting the Course for a Biobased Economy, Hamburg, Germany, 23-26 June 2014; pp. 1706-1710.

11. Ence Energía y Celulosa. Annual Report 2010. Ence, Energía y Celulosa. 2010. Available online: http: / / asp-es.secure-zone.net/v2/index.jsp?id=994/3339/7165\&startPage=14 (accessed on 1 July 2018).

12. Sánchez-Hernando, L.J. ENCE: Una evolución coherente con su pasado más inmediato. Foresta 2011, 50, $74-75$.

13. High Conservation Values Resource Network. Available online: https://www.hcvnetwork.org/ (accessed on 10 September 2018).

14. Brown, E.; Dudley, N.; Lindhe, A.; Muhtaman, D.R.; Stewart, C.; Synnott, T. (Eds.) Common Guidance for the Identification of High Conservation Values; HCV Resource Network: Oxford, UK, 2013; pp. 1-74.

15. Brown, E.; Senior, M.J.M. Common Guidance for the Management and Monitoring of High Conservation Values; HCV Resource Network: Oxford, UK, 2014; pp. 1-66.

16. Forests Stewardship Council. Guidance for Standard Development Groups: Developing National High Conservation Value Frameworks; Draft: FSC-GUI-60 009 V1-0 D1-2 EN; Forests Stewardship Council: Minneapolis, MN, USA, 2017; pp. 1-36.

17. European Commission. Interpretation Manual of European Union Habitats; EUR 28, DG Environment, Nature ENV B.3; European Commission: Brussels, Belgium, 2013; p. 144.

18. Braun-Blanquet, J. Fitosociología, 2nd ed.; Blume: Madrid, Spain, 1979; ISBN 9788472141742.

19. Mueller-Dombois, D.; Ellenberg, H. Aims and Methods of Vegetation Ecology; John Wiley \& Sons. Inc.: Hoboken, NJ, USA, 1974; ISBN 9780471622901.

20. Mucina, L.; Bültmann, H.; Dierßen, K.; Theurillat, J.; Raus, T.; Čarni, A.; Šumberová, K.; Willner, W.; Dengler, J.; García, R.G.; et al. Vegetation of Europe: Hierarchical floristic classification system of vascular plant, bryophyte, lichen, and algal communities. Appl. Veg. Sci. 2016, 19 (Suppl. 1), 3-264. [CrossRef]

21. Rivas-Martínez, S.; Fernández-González, F.; Loidi, J.; Lousã, M.; Penas, A. Syntaxonomical checklist of vascular plant communities of Spain and Portugal to association level. Itinera Geobotanica 2001, 14, 5-341.

22. Decree 23/2012 February the 14th, Regulates the Conservation and Sustainable Use of Wild Flora and Fauna and Their Habitats in Andalusia. Boletín Oficial de la Junta de Andalucía de 27 de marzo de 2012, núm. 60, pp. 114-163. Available online: http:/ / www.juntadeandalucia.es/boja/2012/60/d6.pdf (accessed on 1 July 2018). 
23. Royal Decree 630/2013, August the 2nd, Regulates the Spanish Catalog of Invasive Exotic Flora. Boletín Oficial del Estado núm. 185, de 3 de agosto de 2013; pp. 56764-56786. Available online: https:/ / www.boe. es/boe/dias/2013/08/03/pdfs /BOE-A-2013-8565.pdf (accessed on 1 July 2018).

24. Pascual Horta, L.; Saura, S. Integración de la conectividad ecológica de los bosques en los instrumentos de planificación forestal a escala comarcal y regional. Propuesta metodológica y nueva herramienta de decisión. Revista Montes 2008, 94, 31-37.

25. Saura, S.; Rubio, L. A common currency for the different ways in which patches and links can contribute to habitat availability and connectivity in the landscape. Ecography 2010, 33, 523-537. [CrossRef]

26. Law 42/2007, de 13 de Diciembre, del Patrimonio Natural y de la Biodiversidad. Available online: https: / / www.boe.es/boe/dias/2007/12/14/pdfs/A51275-51327.pdf (accessed on 1 July 2018).

27. FSC Spain. Spanish National Forest Stewardship Standard for FSC Certification (FSC-STD-ESP-01-2006), 2006. Available online: https:/ /es.fsc.org/preview.fsc-std-esp-2006-01-esp-2-0.a-135.pdf (accessed on 10 September 2018).

28. Forest Stewardship Council A.C. Ecosystem Services Procedure: Impact Demonstration and Market Tools (FSC-PRO-30-006), 2018. Available online: https:/ /ic.fsc.org/en/what-is-fsc/what-we-do/ecosystemservices (accessed on 10 September 2018).

29. European Commission. Managing and Monitoring of the Natura 2000 Network; Science for Environment Policy, Thematic Issue 32; European Commission: Brussels, Belgium, 2012.

30. European Commission. Natura 2000 and Forests. Part I-II. Technical Report; European Commission: Brussels, Belgium, 2015; Volume 088.

31. European Court of Auditors, 2017. More Efforts Needed to Implement the Natura 2000 Network to Its Full Potential. Special Report. 68p. EU Bookshop. Available online: http:/ / bookshop.europa.eu (accessed on 10 September 2018).

32. Natura 2000-STANDARD DATA FORM. 2017. Sierra de Aracena y Picos de Aroche. Available online: http:/ / natura2000.eea.europa.eu/ (accessed on 10 September 2018).

33. Red List of Ecosystems. International Union for Conservation of Nature (IUCN). Available online: https: / / iucnrle.org/ (accessed on 10 September 2018).

34. López-Tirado, J.; Núñez Álvarez, A.; Carmona Ruiz, M.I.; Hidalgo, P.J. On the presence of Narcissus scaberulus Henriq. (Amaryllidaceae) in western Andalusia (Spain). Flora Montiberica 2016, 63, 101-102.

35. López-Tirado, J.; Sánchez-Almendro, A.J.; Carrasco-Antelo, J.M.; Hidalgo, P.J. New chorologic contributions to the endangered Isoetes durieui Bory (Isoetaceae, Pteridophyta) in the province of Huelva (Andalusia, Spain). Acta Bot. Malacit. 2015, 40, 274-276. [CrossRef]

36. López-Tirado, J.; Hidalgo, P.J. A new locality for the endangered species Ceratocapnos hererocarpa Durieu (Papaveraceae) to Spain and its syntaxonomical characterization. Acta Bot. Malacit. 2014, 39, 248-253.

37. Costa, M.; Morla, C.; Sainz, H. (Eds.) Los Bosques Ibéricos: Una Interpretación Geobotánica; Planeta: Barcelona, Spain, 1997; ISBN 9788408058205.

(C) 2018 by the authors. Licensee MDPI, Basel, Switzerland. This article is an open access article distributed under the terms and conditions of the Creative Commons Attribution (CC BY) license (http://creativecommons.org/licenses/by/4.0/). 